\title{
GERMAN TAX SYSTEM: DOUBLE TAXATION AVOIDANCE CONVENTIONS, STRUCTURE AND DEVELOPMENTS
}

\author{
Florin Dumiter PhD \\ „Vasile Goldis” Western University of Arad \\ E-mail: fdumiter@yahoo.com \\ Florin Turcas PhD Candidate \\ Bucharest Academy of Economic Studies \\ E-mail turcasflo@gmail.com \\ Anca Opret PhD Candidate \\ Bucharest Academy of Economic Studies \\ E-mail: ancaopret@yahoo.com
}

\begin{abstract}
This paper presents the fundamentals of the tax system in general, the basic elements of a tax system as well as the organization of the German tax system analysis, especially throughout the tax levy and how the taxation typology functions. This theme was chosen in order to expose the principles of German taxation system. With a tumultuous and troubled history, mainly caused by the two World Wars' destructions, the German state is considered the „economic locomotive” and a pillar of the European Union. Germany's economy is mainly driven by the automotive industry, chemical industry, telecommunications, commerce and agriculture. Of particular importance is the qualitative analysis of conventions for the avoidance of double taxation concluded by Germany; and related implications on fiscal policy. The methodology used in this paper consists of presenting literature derived theories and practical analysis of the German tax system in terms of tax legislation and the evolution of double taxation conventions concluded by Germany with different countries. After the study, the conclusions on the size of the national tax system driven by the example of the German tax system were founded.
\end{abstract}

Keywords: judicial double taxation, fiscal policy, double taxation conventions, German fiscal system.

\section{Introduction}

The concept of finance appeared concomitantly with the rise of organized human communities. The emergence of states, the evolution of society and economic development have led to the tax systems formation, their original role was the procurement of state resources, necessary to cover administrative expenses and infrastructural development.

Market and economic state interventionist failure, led to the rise in importance of the state finance and taxation. Since the nineteenth century, finances are treated as an independent discipline within the field of economics. 


\section{JOURNAL OF LEGAL STUDIES}

"Vasile Goldiș" Western University of Arad

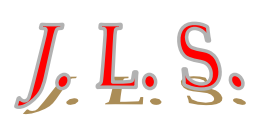

Dumiter, F., Turcas, F., Opret, A. (2015)

German tax system: double taxation avoidance conventions, structure and developments

The field of „Public Finance” studies how the state procures and uses financial resources to achieve its financial, economic and social goals.

Different historical periods record a continuous evolution of tax systems based on the socio-economic and political ideology imposed at state level. This improvement persists today due to the fact that globalization and the development of economic, financial and commercial international exchange systems have set connection between different national taxation systems, hence, imposing their harmonization and convergence at international level.

Thus, taxation and the structure of tax systems is a topic frequently discussed in the economic literature, especially given the importance of acknowledging leverages that determine the efficiency of tax systems.

With the advent of the state, the evolution of society, the increasing role of the state, the development of production factors and monetary relations the concept of taxation appeared and was defined.

Taxation is defined, in economic terms, as the way through which tax revenues and states budgets are „fed". Taxation is ,a set of monetary economic processes, of growth domestic product redistribution from a natural or legal person to the state, for covering public consumption needs, involving the interaction between procurement and allocation of spoken resources"1.

In light of the legal framework, taxation is a set of concepts, principles, methods and processes deployed to levy taxes and contributions in accordance with the tax legislation in force.

According to (DEX, 2009) taxation is defined as „encompassing all laws, regulations and tax arrangements related to tax methods" and as a "process of mobilizing and allocating financial resources needed by the state" ${ }^{2}$. The conclusion of a definition for taxation is drawn from Larousse dictionary ,total charged fees; all laws concerning taxes".

Taxation is the expression of the political will of an autonomous, sovereign and organized on a geographical region community, to implement, through representative legal bodies.

Together, these two essential characteristics of the fiscal and taxation system, namely the exclusivity of application and technical autonomy, take shape. Exclusivity grants the geographical delimited appointed state the authority to be the sole collector of resources in the territory. Autonomy is given by the existence of all necessary elements of taxes, fees and contributions.

Developing fiscal rules in respect to these two characteristics by the representative bodies of a state, confers its fiscal sovereignty, manifested by the freedom to choose the desired tax system and is manifested by defining perceived taxes and contributions, establishing the taxpayers and taxable mass, the tax quota and determining their payment deadlines and setting conditions for tax incentives and 


\section{JOURNAL OF LEGAL STUDIES}

"Vasile Goldiș" Western University of Arad

Dumiter, F., Turcas, F., Opret, A. (2015)

German tax system: double taxation avoidance conventions, structure and developments

how to sanction violations of the law and how to resolve litigations. Also, tax sovereignty of a commonwealth prevents other states, agencies or national organizations to establish and issue tax regulations binding at international level.

In the current context, state taxation, due to globalization and economic integration, which is possible due to free movement of goods, people, services and capital, produces significant changes in the structure of other states. Thus, due to interstate cooperation, the need for a proximity and harmonization of tax systems arises, mainly to support the equity in allocation and to prevent harmful competition.

Tax levy, whether in form of taxes, charges or contributions shows a complex financial, economic, politic and social role, different for each stage of economic development.

The financial role is of utmost importance due to the involvement of financial resources, raised through levies, in the structure of state budget and public expenses.

Economically, by tax levies, the state has a mean of intervention in economic activity, by influencing the increase or decrease in the level of production and consumption of a product, by stimulating or inhibiting international trade or by reducing different types of activities.

In what regards the political role, it plays a part in terms of promoting an income tax with some form of tax levy in order to achieve socio-political objectives.

The social role of tax levy is reflected in the distribution of a percentage of the gross domestic product to natural and legal people, belonging to different social classes and categories.

\section{Theoretical assessments regarding the tax system}

Taxation system is a part of the important tools used by the state to direct economic and social activity and to fulfill its duties.

A tax system is framed by two parameters, namely the space and time in which it acts. The space parameter is defined by the geographical territory in which it operates, whereas the time parameter reflects the annual nature of the financial year.

The tax system is defined as an assembly of all the concepts, principles, methods and processes, and of the relationship between the components managed in accordance with the legislation in force for achieving the targets.

Tax system components are:

- Tax legislation;

- All taxes and contributions;

- Tax mechanism;

- All methods, techniques and fiscal instruments;

- Tax apparatus. 


\section{JOURNAL OF LEGAL STUDIES}

"Vasile Goldiș" Western University of Arad

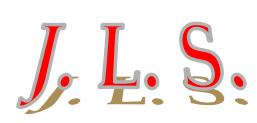

Dumiter, F., Turcas, F., Opret, A. (2015)

German tax system: double taxation avoidance conventions, structure and developments

Tax legislation establishes the organizational and management of financial activities, the competences, rights and obligations of specialized bodies and taxpayers to ensure a proper evolution of the activity.

Legal regulations are in the form of laws passed by parliament, government decision ratified by Parliament, orders of the Minister of Economy, Finance, Governor of Central Bank presidents, other financial institutions, as well as the rules and regulations developed by ministries, institutions or local bodies.

Under existing legislation, enforcement authorities implement financial decisions ensuring the organization, the management and the effective deployment of financial activity through specialized financial institutions.

Tax mechanism is a functional component of the economic mechanism, consisting of structures, methods, principles and specific leverage finance, concretely manifested by organizing financial-monetary flows, the creation, distribution and usage. In a market economy this mechanism is based on self-regulation and adaptability to the ongoing financial flows. When economic instability arises and self-regulation is no longer performed, the state tries to exert a favorable influence on consumption through a discreet intervention, using different financial leverages. Financial leverages are tools commonly used by the state to correct, encourage, stimulate and harmonize the economy and implementation of public interests. Among the used leverages: tax, tax exemptions and surcharges, tariffs, subsidies and allowances can be recalled.

All these are coordinated by the financial apparatus, consisting of financial and banking institutions and specialized bodies. Their role is to conduct, manage and supervise operations of financial nature. The institutions and specialized bodies in Germany are: Federal Ministry of Finance and state authorities, Alcohol Monopoly Federal Authority, Federal Central Tax Office, federal financial offices, Customs Criminological Office, customs offices and agencies, special tax income offices.

Tax system functionality is given by the quality of relationships between these components and the human-factor. Compliance with techniques, principles and rules lead to stability in what regards the taxation, economic, social and political system.

In order for a tax system to fulfill its role, six principles must be followed:

1. Equity through a non-discriminatory tax treatment and enforced in the same way by the contributory power.

2. Efficiency by maximizing taxation at the lowest possible cost to taxpayers. Higher taxation inhibits consumption and savings, affecting economic efficiency.

3. Simplicity achieved through clear, understandable legislation, which prevents evasion of payment of taxes and contributions, and at the same time offers ease of administration at a low cost. 


\section{JOURNAL OF LEGAL STUDIES}

"Vasile Goldiș" Western University of Arad

Dumiter, F., Turcas, F., Opret, A. (2015)

German tax system: double taxation avoidance conventions, structure and developments

4. Flexibility, the ability to adapt to the economic situation, which is in constant change.

5. Stability afforded by enduring tax legislation over a longer period of time, which receives confidence and acceptance from taxpayers.

6. Transparency through informing on the usage of revenues from taxes and contributions.

The economic environment fluctuates, due to different reasons and with different amplitudes that can produce stagnation or even recession. These failures must be reduced, the tax system having the role to balance state interests with the socioeconomic environment.

In this case, fiscal policy decisions, which provide structural modeling and functionality of the tax system, must be correlated with the budgetary policy, exchange rate policy, monetary policy and trade policy.

Fiscal policy is "a main component of financial policy, which can be promoted only by the State or public authorities and covering both decisions (regulations) regarding the stability and the levying of taxes by setting up options in terms of taxes, and on financed public expenditures"3.

Fiscal policy determines the amount of necessary financial state resources needed to cover committed expenditures, the origin of such resources, methods of levy, number of taxes, tax rates and tax burdens.

The role of fiscal policy is to maintain budgetary balance. Thus, there is a close connection between fiscal policy and budgetary policy, "given that, as the level increases and diversifies the structure of public expenditure, it is necessary to find sources of additional public revenues, most of it by increasing tax levies" ${ }^{\prime}$.

As mentioned above, the emergence and development of tax systems are reflected in social and economic structures, political currents and ideologies and scientific research, carried out in the economic field.

Tax systems have formed since antiquity and were different for each unit, collection of taxes was irregular and in what concerns imposition it was unfair. In ancient Greece lands, craftsmen revenues and revenues from marketing of agricultural products were subjected to taxation. Extraordinary, during war periods the aristocracy's revenues was also taxed. In the Roman Empire, „tributum” was only claimed in conquered territories, and only latter acquired a permanent character, being imposed on all citizens owning properties. Also incomes from goods trade and craft activities were taxed.

In the Middle Ages, tax systems have been influenced by the traditions of each state, tax privileges were preserved. In England, Libertatum Charter had forbidden taxation without the approval of the people. Taxation was done according to the social status of the tax payer and taxed assets, revenues obtained from crafting and exploitation of natural resources was also taxed. In Florence revenues by exploiting 


\section{JOURNAL OF LEGAL STUDIES}

"Vasile Goldiș" Western University of Arad

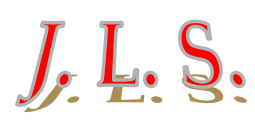

Dumiter, F., Turcas, F., Opret, A. (2015)

German tax system: double taxation avoidance conventions, structure and developments

natural resources were subjected to taxation, and there were also custom taxes on goods and taxes on succession shares.

Modern Age brought artistic, literary, scientific and technological progress. Reform of tax systems began with the formulation of the classical principles of taxation by Adam Smith: certainty of taxation, levying of convenience, fairness and economicity in taxation. Public finances have undergone a process of organizational and administrative centralization, and in respect of taxation, tax privileges have disappeared and indirect taxes have increased. After the French Revolution, the continuous modernization of tax systems continued by the adoption of new ways of settling synthetic and personal and economic entities (requiring progressive rates, surcharges) taxation.

The twentieth century showed a progressive increase in the number of tax payers, in accordance with the increase of tax return. Tax systems at the time were found at the limit of Keynesian and monetarist doctrine.

Keynesianism's supporters considered the market to be imperfect and the main cause for economic disruption, fact which required government intervention. The objective of economic policy is economic stability and growth, the main instrument used for this is economic fiscal policy, which has the role to maintain conditions that stimulate investment.

Monetarism supports liberalization through a policy that disapproves state intervention in the economy. The main objective of economic policy is to maintain price stability mainly through monetary policy. Regarding fiscal policy, it is subject to monetary policy and has an important role in cases of currency variations.

The two extreme "perceive economic reality using the same „macro" methodology, however, monetarists focus on the long term and consider that there is a direct connection between money and real phenomena. On the other hand, Keynesians perform a short term analysis, and are very skeptical in regard to the existence of any link between money and real phenomena, which can in any way guarantee that an equilibrium position will attained and maintained"5.

An important role in the economic development, and implicitly in the tax system is held by international organizations: Organization for Economic Co-operation and Development (OECD), the European Carbon and Steel Community (ECSC), the European Economic Community (EEC), the World Trade Organization and others Nowadays, national tax systems are subjected to globalization. The formation of the European Union and the free movement of goods, services, people and capital should be in harmony and convergence with tax laws. „Fiscal harmonization, symbol of national sovereignty, remains a delicate issue due to its complexity and the appliance of the unanimity rule in the decision-making process ${ }^{\text {"6 }}$, but also from the danger of undermining autonomy and sovereignty. 


\section{JOURNAL OF LEGAL STUDIES}

"Vasile Goldiș" Western University of Arad

Dumiter, F., Turcas, F., Opret, A. (2015)

German tax system: double taxation avoidance conventions, structure and developments

In the single market perspective, direct taxation does not require harmonization as long as the four freedoms are maintained. In what concerns double taxation, the fiscal residence is determined by inter-state agreements.

Conversely, indirect taxation requires a high level of harmonization because it touches the free movement of goods and the freedom to provide service. Thus, at European level, for exchanges between countries there are no charged custom fees, and at international levy, these fees are regarded as barriers standing in the way of the devolvement of free trade, hence, determined the signing of agreements stipulating preferential terms regarding custom fees. „All European Union member states establish their indirect taxes, ie VAT and excise duties, according to the provisions of Community Directives, Directive containing both general principles for establishing such taxes and minimum levels required."7 On VAT, the Union stated that it is the only form of tax on turnover, tax rates vary between $15 \%$ and $25 \%$, with a maximum of two reduced rates. The European Union has smoothly regulated the excise applicable throughout its borders, without exception; the duty to determine fiscal policy in relation to applied rates will be in the hands of the member states.

State fiscal policies must be adapted to each national and international environment to ensure an orderly functionality of the market. In this context, there is " $a$ competition between Member States' tax jurisdictions in which everyone wants to make it fiscally attractive for different categories of taxpayers direct or indirect" ${ }^{\prime 8}$.

The promotion of fiscal policies that favor mobility of capital and labor produces a transfer of fiscal burdens and an economic, financial and social imbalance. Current tax systems must ensure social and economic stability and prevent harmful tax competition'.

As a conclusion to the above, ,growing economic interdependence entailed a loss of sovereignty of economic national authorities and a reduction in the economic capacity to achieve its internal objectives in an independent way, their actions being subordinated to market discipline, which require the application of credible economic policies that guarantee stability. However, it is obvious that the development of financial market and the growing economic globalization may improve the effectiveness of national policies in seeking their goals, as long they win credibility and will positively influence the expectations of economic agents"3.

\section{German Tax System}

Germany is a federal republic made up of 16 Länder (states), each with its own constitution, its own government and its own independent tribunal. Federal Government and Parliament are responsible for most financial and economic policy legislation. 


\section{JOURNAL OF LEGAL STUDIES}

"Vasile Goldiș" Western University of Arad

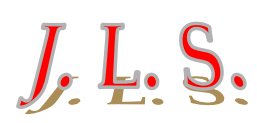

Dumiter, F., Turcas, F., Opret, A. (2015)

German tax system: double taxation avoidance conventions, structure and developments

The German tax authorities administering the tax system are organized into the following levels:

- Federal Ministry of Finance and Member State authorities;

- Alcohol Monopoly Authority and the Federal Central Federal Tax Office;

- Federal financial offices, regional offices and the Office of Criminology Customs Financial;

- Offices and customs agencies, customs investigation offices, tax offices and special revenues of the Länder.

The subject of each authority and jurisdiction is established by law and includes residence, domicile, and headquarters of companies, agriculture and real estate.

Industry and related services are the heart of the German economy. The automotive industry, chemical industry and telecommunications are the most important, steel production in the Ruhr region and the importance of agriculture is in decline.

Germany is among the first countries trade - related, having a high level of exports, but also significant imports. The main trading partners are the European Union's countries and the United States.

Germany is a member of the European Union, the Organization for Economic Cooperation and Development and the World Trade Organization. As an EU member, it must comply with European directives and regulations on trade treaties, import regulations, customs, agricultural agreements, import quotas, rules of origin and other trade regulations.

Companies operating in Germany have access to a free consumer market through its membership in the EU and free trade with Iceland, Liechtenstein, Norway and Switzerland through other agreements.

The banking system includes all funding forms from German or foreign investment banks, mortgage institutions and insurance companies. Commercial banks are the main source of capital for foreign companies. All major commercial and investment banks operate in Germany; Frankfurt being the financial center

Regarding business, the German Government admits foreign direct investments which provide new jobs. There are no serious limitations on new projects except the law which requires prior approval for the sale of government defense companies to foreign investors.

Under the law of foreign trade, the government can prevent or apply restrictions on the acquisition of an entity by a non-EU if this is necessary to maintain law and order. No financial or administrative control is applied for foreign investments. Foreign investors are subject to the same conditions as German investors for obtaining operating licenses, securing permits and approvals for special investment incentives.

Tax incentives are granted through various programs that promote modern forms of energy generation, environmental protection, research and development, health and 


\section{JOURNAL OF LEGAL STUDIES}

"Vasile Goldiș" Western University of Arad

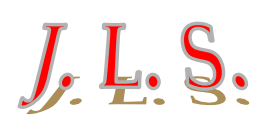

Dumiter, F., Turcas, F., Opret, A. (2015)

German tax system: double taxation avoidance conventions, structure and developments

care, infrastructure and agriculture. In this regard, there are federal and regional programs. The promotion is supported in forms of tax benefits, allowances, credits or loans.

Regarding cash flows, Germany has a liberal policy. There are no foreign exchange controls in ordinary commercial transactions and companies have unlimited access to borrow credit. External financing is facilitated by full convertibility of the euro and by free external exchange. However for statistical purposes Central Bank, the Bundesbank, must be informed of incoming and outgoing transactions.

The main taxes German companies pay are income tax, municipal trade tax, value added tax and social security contributions. Other charged taxes charged: immovable property tax, the tax of real estate transferred properties, customs and excise duties.

Germany has implemented EU directives on interest, royalties and merger as well as economic directives, which require the exchange of information between tax administrations when making payments between a Member State and a resident in another Member State.

Tax laws are passed by the House of Deputies of the Parliament. Federal tax law requires the consent of the Federal Council if the revenues accrue completely or partly to states or municipalities. States have the authority to legislate with respect to local taxes on consumption and to extend such charges which are not similar substantially covered by federal law. They are empowered to set the tax rate for real estate acquisition.

Tax authorities may be authorized by law to issue regulations. Federal Ministry of Finance and the local tax authorities may issue administrative leading decrees about certain aspects of tax law.

Tax authorities are responsible for enforcement and tax collection. They are organized in local departments in Member and federal department, each with different skills depending on the tax and involved taxpayers. Local authorities collect taxes dependent on the taxpayer's residence or the registered office of the entity. At federal level, international tax issues are managed, for example credit or exemption from withholding taxes, gathering information or international administrative assistance.

In what concerns resident entities, companies with registered office or other space management and German control are considered to be resident in Germany. Foreign companies which have their registered office or other space management and control in Germany are considered to be resident.

In the absence of a treaty or in a treaty situation which provides a tax credit, German taxpayers with income from foreign sources may credit foreign taxes paid to the extent that such income is subject to taxation under the law. Alternatively, 


\section{JOURNAL OF LEGAL STUDIES}

"Vasile Goldiș" Western University of Arad

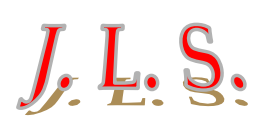

Dumiter, F., Turcas, F., Opret, A. (2015)

German tax system: double taxation avoidance conventions, structure and developments

taxes paid abroad can be deducted as business expenses. If the income is exempt from taxation in Germany, the deduction of tax credit will not be possible.

Germany has an extensive network of tax treaties, most of them following the OECD model. The treaties generally provide the avoidance of double taxation for all types of income, limiting the level of taxation to a single state and protection of the resident companies from discriminatory taxation in other states.

Following a treaty, reduced rates of withholding tax can be directly applied in the payment moment, if the owner completes and submits the necessary income forms to the Central Federal Tax Office.

The fiscal year is generally the calendar year, but resident companies can choose different fiscal year from the calendar year. Choosing a different fiscal year can be achieved only with the tax authorities approval, the comeback to the calendar year can be done without this agreement. The fiscal year cannot be longer than 12 months but may be shorter.

Companies' taxes are set annually, but the payment is made in advance, in quarterly installments rates on March $10^{\text {th }}$, June $10^{\text {th }}$, September $10^{\text {th }}$ and December $10^{\text {th }}$. Municipal taxes are due on February $15^{\text {th }}$, May $15^{\text {th }}$, August $15^{\text {th }}$ and November $15^{\text {th }}$ of each year.

General tax declaration must be submitted by $31^{\text {st }}$ of May of the following year. If a tax consultant prepares the statement, the due date shall be extended until $31^{\text {st }}$ of December in following year; the tax authorities may require the taxpayer to fill the declaration before that date. Late unauthorized payments are subject to penalties, usually $1 \%$ of the outstanding amount per month plus a fine, depending on the situation.

As of 2011, income tax statements and municipal trading tax declarations must be submitted electronically. Additionally, taxpayers who use double-entry accounting system to calculate taxes should submit European tax balance.

Employers are responsible for withholding taxes of their employees. The tax must be paid monthly to all employees if the previous year total payroll tax exceed 4000 euros and quarterly if the total falls between 1000 and 4000 euros. If the total taxes do not exceed 1000 in the previous year, payment will be made once a year.

Prescription Regulation is 4 years from the end of maturity. The prescription is 10 years, 5 years for fraud and negligence. The period during which taxes are collected is 5 years.

Table 1 summarizes the main taxes levied in Germany and quotas for their application.

\section{Double taxation conventions: the German Experience}

A convention on international double taxation constitutes a mutual agreement concluded between two countries to prevent the taxpayer of a country, or in certain 


\section{JOURNAL OF LEGAL STUDIES}

"Vasile Goldiș" Western University of Arad

Dumiter, F., Turcas, F., Opret, A. (2015)

German tax system: double taxation avoidance conventions, structure and developments

cases in both countries, to be taxed on the same income or capital in both countries. The situation in which two countries or in some cases several countries, subject to taxation the same taxpayer for the same income or capital is known as juridical double taxation.

Table 1. The main economic taxes and tax rates applied to entities in Germany

\begin{tabular}{|l|r|}
\hline \multicolumn{1}{|c|}{ Tax } & \multicolumn{1}{|c|}{ Tax rate } \\
\hline Income tax & $15 \%$ \\
\hline Municipal trade tax & $14 \%-17 \%$ \\
\hline Tax on capital income & $25 \%$ \\
\hline Dividend tax & $0 \%$ \\
\hline Participating interests tax & $5,5 \%$ \\
\hline Solidarity surcharge & 19\% (reduced rate $-7 \%$ ) \\
\hline VAT & $3,5 \%-5 \%$ \\
\hline Real estate tax & \multicolumn{2}{|c|}{ Source: Germany Taxation and Investment, $2013{ }^{10}$} \\
\hline \multicolumn{2}{|c}{}
\end{tabular}

Double taxation occurs because most states tax their residents (both individuals and companies) based on total annual income, whether income arises in the home country or abroad. Besides taxing people who are subject to taxation, countries are taxing people doing various activities carried out within its territory.

Moreover, besides the above-mentioned legal double taxation, economic double taxation arises when two different people are taxed on the same income or capital.

Considering the Convention for the avoidance of double taxation concluded by Germany, Annex 1 shows, in short, a true image of them. As can be seen, according to Annex 1, Germany has concluded over 100 double taxation conventions with different countries. Among these conventions, the most commonly used is the income and capital completed by nearly 90 countries, the First Convention on income and capital is with Luxembourg signed on 23.08.1958 and most recently completed one is with Ireland on 30.03.2011.

Regarding income conventions concluded by Germany, these target endorsement agreements with countries such as Cyprus (18.02.2011), Jersey (04.07.2008), Malaysia (23.02.2010), Syria (17.02.2010) and the UAE (01.07.2010).

Referring to other types of conventions for the avoidance of double taxation concluded by Germany, analyzing annex 1, the following can be seen: Convention concluded in respect of succession (17.09.2004) with Austria, inheritance and gift (30/11/1978) with Switzerland, successions and donations (12/03/1980) with the US, collaboration protocol type conventions with Japan (02.17.1983), Luxembourg (06.15.1973) and the USA (14.12.1998). 


\section{JOURNAL OF LEGAL STUDIES}

"Vasile Goldiș" Western University of Arad

Dumiter, F., Turcas, F., Opret, A. (2015)

German tax system: double taxation avoidance conventions, structure and developments

In what concerns avoidance of double taxation conventions Affecting transport, Germany concluded the following conventions: Convention on air transport with Ivory Coast (07/03/1979) Convention on maritime transport with Hong Kong - site (13.01.2003) and aviation and nautical transport convention with Venezuela (23/11/1987). Furthermore, besides these kinds of double taxation conventions Germany has concluded a type Covent technical / administrative / arbitration with the US on 19/08/1989.

\section{Conclusions}

Within the state, the tax system is the element that ensures the stability and development of society. The tax system is framed by the space and time in which it operates, each state enjoying exclusivity in taxation and in terms of defining the elements necessary for the application of taxes and contributions.

The tax system consists of tax legislation in force, the total tax levy, tax mechanism, all the methods, techniques and tools used to tax, all of which are coordinated by the tax system through specialized financial banking bodies.

Through tax law the organization and management of financial activities, competences, rights and obligation of taxpayers and tax authorities is established.

Tax levies are state resources that provide development, support consumption, social protection and finance for all expenditure incurred by the State. Levies must meet the practical form of tax, fee or contribution.

Taxation is a general, definitive and non-reciprocal pecuniary obligation, claimed by authorities from legal and natural people, under the terms and conditions set by the tax legislation. Tax payment is coercively imposed by the state to all natural and legal people that generate income, profit or have a form of wealth. Taxation conditions, the amount and payment terms are set by law, on taxpayers categories. The tax is of non-refundable nature, is a resource of the state budget and does not have a direct and immediate consideration.

The tax is a form of fiscal levy with a pecuniary character, imposed by public authority to legal and natural people for a rendered service, a right held or for some cases for certain goods in the form of taxation.

Contributions are specific tax levies with intermediate characteristics between taxes and fees. They have a pecuniary and mandatory, being set by the state in connection with a benefit of social, economic or public nature.

Levies, regardless of their nature, submit a financial role by their belonging to the state budget and by covering expense, an economic role by intervention on production, consumption and trade, a social role given by the GDP redistribution and a political role by promoting taxation with certain forms of tax levy.

Tax imposition must respect the principles of tax fairness, fiscal policy, economic policy and social policy principles. 


\section{JOURNAL OF LEGAL STUDIES}

"Vasile Goldiș" Western University of Arad

Dumiter, F., Turcas, F., Opret, A. (2015)

German tax system: double taxation avoidance conventions, structure and developments

Tax equity implies taxation equality, depending on the strength of each taxpayer. In this regard, a non-taxable minimum must be established, the imposition must be universal in balance with contributive power and fiscal privileges must not exist. In compliance with this principle tax rates have a major role. They can be proportional, regressive or progressive depending on the role that must be met.

Principles of fiscal policy aim at fiscal efficiency, flexibility, stability, and on the number and type of taxes imposed.

The principles of economic policy require the imposition of taxes and contributions as levers for economic recovery and investment encouragement.

Socio-political policies aim at ensuring balance on the distribution of tax burdens.

Fiscal mechanism includes structures, methods, principles and specific levers used to organize the financial sector, the creation, distribution and use of resources. In a market economy, these structures are self-regulatory and adapt to the economic environment. In terms of economic instability, different leverages are used to intervene for the stability insurance.

The functionality of tax system is given by the quality of relationships between these elements and the human factor. Techniques, principles and rules compliance lead to stability in the tax economic, social and political system.

The tax system has four important functions in the national economy, namely: revenue mobilization function, function to stimulate the economy, social protection function and economic fluctuations 'control function.

An effective tax system should meet the following principles: equity, efficiency, simplicity, flexibility, stability and transparency.

Germany's prevailing tax levy are direct taxes imposed on income and profit, social security contributions and indirect taxes imposed on goods and services.

From the above, it can be inferred that levy mainly affect revenues of individuals. Imposing higher taxes can be harmful due to the decrease in the level of savings, lack of investment and lower living standards.

The German tax system is impressive through its organization and complexity. Its main characteristic is stability. Analyzing the world economic crisis - it can be noted that it was the fiscal system that maintained and helped recover the German economy, in a relatively short time, given the fact that there are countries that still struggle nowadays.

Analyzing over 100 conventions for the avoidance of double taxation concluded by Germany it can be noted that such a developed country can be regarded as an archetype in terms of network conventions for the avoidance of double taxation. Furthermore, it can be noted that the more developed a country is the more developed are its commercial channels on the movement of goods, services, capitals and people, and implicitly the conventions of avoiding double taxation in 


\section{JOURNAL OF LEGAL STUDIES}

"Vasile Goldiș" Western University of Arad

Dumiter, F., Turcas, F., Opret, A. (2015)

German tax system: double taxation avoidance conventions, structure and developments

order to facilitate the exchange of goods and services, free movement of capital and work force, both on EU and worldwide level.

\section{References}

[1] Vintila, N., Filipescu, M.O., Lazar, P., (2013), Fiscalitate aplicata si elemente de management fiscal, Ed. C.H. Beck, Bucuresti.

[2] Vlaicu, A.N., (2007), Tratat de finante generale, Ed. Casa Cartii de Stiinta, Cluj-Napoca.

[3] Chirlesan, D., (2008 b), Metodele actiunii bancare si gestiunea finantelor publice, vol. 2, Ed. Universitatii „Al. I. Cuza”, Iasi.

[4] Cioponea, M.C. (2007), Finante publice si teorie fiscala, Ed. Fundatiei Romania de Maine, Bucuresti.

[5] Chirlesan, D., (2008 a), Metodele actiunii bancare si gestiunea finantelor publice, vol. 1, Ed. Universitatii „Al. I. Cuza”, Iasi.

[6] Brezeanu, P. (2007), Finante europene, Ed. C.H. Beck, Bucuresti.

[7] Tatu, L., Serbanescu, C., Stefan, D, Catarama, D., Nica, A., Miricescu, E.C., (2013), Fiscalitate: de la lege la practica, Ed. C.H. Beck, Bucuresti.

[8] Chilarez, D., Ene, G.B., (2014), Harmonisation and fiscal competition in the

European Union, Management Strategies Journal, vol. 23, issue 1, pag. 83-93

[9] Georgescu, M.A., (2009), Administrarea finantelor publice si a bugetului, Ed. Pro Universitaria, Bucuresti.

[10] *** Taxation and investment in Germany 2013: Reach, relevance and reliability, A publication of Deloitte Touche Tohmatsu Limited, (2013).

http://ec.europa.eu/eurostat/data/database, accessed on 14.03.2015.

http://stats.oecd.org, accessed on 03.04.2015. 


\section{Total number of international agreements to avoid double taxation concluded by Germany}

\begin{tabular}{|c|c|c|c|}
\hline $\begin{array}{l}\text { Country that } \\
\text { concluded the } \\
\text { agreement }\end{array}$ & Partner country & Agreement type & Date \\
\hline \multirow[t]{33}{*}{ Germany } & Albania & Income and capital & 06.04 .2010 \\
\hline & Algeria & Income and capital & 12.11 .2007 \\
\hline & Argentine & Income and capital & 16.09 .1996 \\
\hline & Australia & Income and capital & 24.11 .1972 \\
\hline & Austria & Income and capital & 24.08 .2000 \\
\hline & Austria & Successions & 17.09 .2004 \\
\hline & Azerbaijan & Income and capital & 25.08 .2004 \\
\hline & Bangladesh & Income and capital & 29.05 .1990 \\
\hline & Belarus & Income and capital & 30.09 .2005 \\
\hline & Belgium & Income and capital & 11.04 .1967 \\
\hline & Bolivia & Income and capital & 30.09 .1992 \\
\hline & Brazil & Income and capital & 27.06 .1975 \\
\hline & Bulgaria & Income and capital & 25.01 .2010 \\
\hline & Canada & Income and capital & 19.04 .2001 \\
\hline & China & Income and capital & 10.06 .1985 \\
\hline & Costa Rica & Income and capital & 25.01 .1993 \\
\hline & Croatia & Income and capital & 06.02 .2006 \\
\hline & Cyprus & Income & 18.02 .2011 \\
\hline & Cyprus & Income and capital & 09.05 .1974 \\
\hline & Cyprus & Income and capital & 18.02 .2011 \\
\hline & Czech Republic & Income and capital & 19.12 .1980 \\
\hline & Denmark & Income and capital & 22.11 .1995 \\
\hline & Ecuador & Income and capital & 07.12 .1982 \\
\hline & Egypt & Income and capital & 08.12 .1987 \\
\hline & Estonia & Income and capital & 29.11 .1996 \\
\hline & Finland & Income and capital & 05.07 .1979 \\
\hline & France & Income and capital & 20.12 .2001 \\
\hline & Greece & Income and capital & 18.04 .1966 \\
\hline & Greenland & Income and capital & 28.03 .2000 \\
\hline & Hong Kong & Nautical transport & 13.01 .2003 \\
\hline & Hungary & Income and capital & 18.07 .1977 \\
\hline & Hungary & Income and capital & 28.02 .2011 \\
\hline & Iceland & Income and capital & 18.03 .1971 \\
\hline
\end{tabular}




\section{JOURNAL OF LEGAL STUDIES}

"Vasile Goldiș" Western University of Arad

Dumiter, F., Turcas, F., Opret, A. (2015)

German tax system: double taxation avoidance conventions, structure and developments

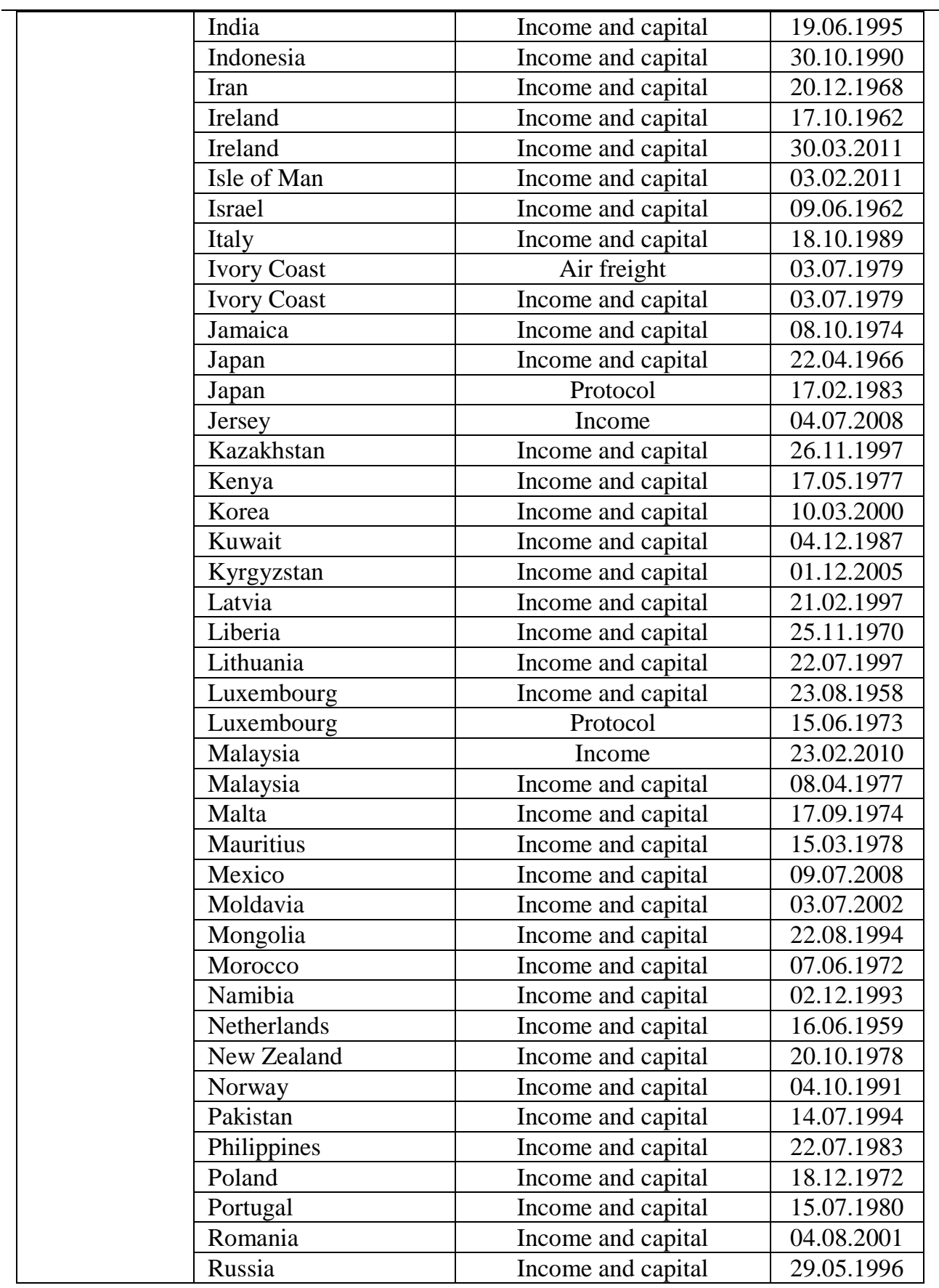




\section{JOURNAL OF LEGAL STUDIES}

"Vasile Goldiș" Western University of Arad

Dumiter, F., Turcas, F., Opret, A. (2015)

German tax system: double taxation avoidance conventions, structure and developments

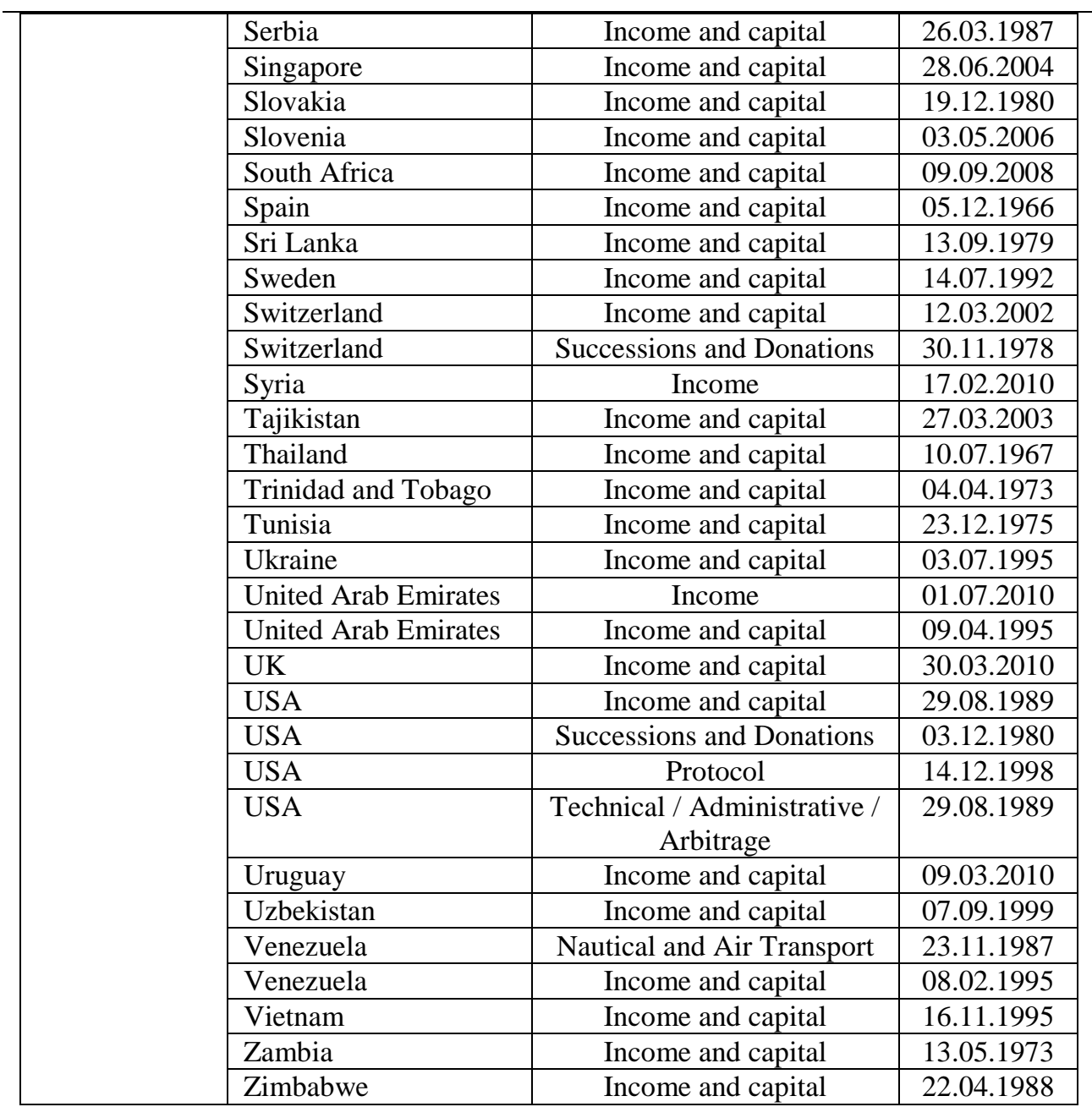

Source: Authors' development based on data available in the database of the Conference on Trade and Development, United Nations 